\title{
Climate variability and EI Niño Southern Oscillation: implications for natural coastal resources and management
}

\author{
Sven Thatje $\cdot$ Olaf Heilmayer $\cdot$ Jürgen Laudien
}

Received: 30 October 2007 / Revised: 14 December 2007 / Accepted: 20 December 2007 / Published online: 5 February 2008 (C) Springer-Verlag and AWI 2008

\begin{abstract}
The El Niño Southern Oscillation (ENSO) significantly influences marine ecosystems and the sustained exploitation of marine resources in the coastal zone of the Humboldt Current upwelling system. Both its warm (El Niño: EN) and cold (La Niña: LN) phase have drastic implications for the ecology, socio-economy and infrastructure along most of Pacific South America. Local artisanal fisheries, which especially suffer from the effects of EN, represent a major part for the domestic economy of Chile and Peru and in consequence a huge amount of published and unpublished studies exists aiming at identifying effects of EN and LN. However, most processes and underlying mechanisms fostering the ecology of organisms along Pacific South America have not been analyzed yet and for the marine realm most knowledge is traditionally based on rather descriptive approaches. We herein advocate that small-scale comparative and interdisciplinary process studies work as one possible solution to understand better the variability observed in EN/LN effects at local scale. We propose that differences in small-scale impacts of ENSO along the coast rather than the macro-ecological and oceanographic view are essential for the sustainable management of costal ecosystems and the livelihood of the people depending on it. Based on this, we summarize the concep-
\end{abstract}

Communicated by S. Thatje.

S. Thatje $(\varangle) \cdot$ O. Heilmayer

National Oceanography Centre, Southampton,

School of Ocean and Earth Science, University of Southampton,

European Way, Southampton SO14 3ZH, UK

e-mail: svth@noc.soton.ac.uk

J. Laudien

Marine Animal Ecology,

Alfred Wegener Institute for Polar and Marine Research,

PO Box 120 161, 27515 Bremerhaven, Germany tual approach from the EU-funded International Science and Technology Cooperation (INCO) project "Climate variability and El Niño Southern Oscillation: Implications for Natural Coastal Resources and Management (CENSOR)" that aims at enhancing the detection, compilation, and understanding of EN and $\mathrm{LN}$ effects on the coastal zone and its natural resources. We promote a multidisciplinary avenue within present international funding schemes, with the intention to bridge the traditional gap between basic and applied coastal research. The long-term aim is an increased mitigation of harm caused by EN as well as a better use of beneficial effects, with the possibility to improve the livelihood of human coastal populations along Pacific South America and taking differences between local socio-economic structures of the countries affected by EN into consideration. The success of such an approach however, does finally rely upon a willingness of the recourse users and the various political and economic stakeholders involved to taking on the message as part of sustainable management strategies.

Keywords ENSO $\cdot$ South America $\cdot$ Upwelling · Humboldt Current $\cdot$ Artisanal fisheries · Ecosystem management $\cdot$ Climate oscillation

\section{ENSO along the western Americas}

Eastern Boundary Currents play a decisive part in the budgets of both the Pacific and the Atlantic Ocean, including latitudinal heat exchange, ocean-atmosphere interactions, organism transport and genetic interchanges. They are the great motors of the circular oceanic current systems, transporting cold water into tropical and equatorial regions, and highly efficient ecosystems in which nutrients are returned 
to the surface layers of the ocean where they can be used by photosynthetic primary producers (Thiel et al. 2007, and references therein).

In recent years monitoring of the sea surface temperature in eastern boundary currents of the Pacific Ocean (Humboldt Current off Chile and Peru, Fig. 1; California Current off USA and Mexico) has illustrated that the El NiñoSouthern Oscillation (ENSO) is an interannual climate oscillation between warm phases (El Niño: EN) and enhanced cold phases (La Niña: LN) (Figs. 2, 3). These two stages of the ecosystem emerge from a background of "normal" conditions, which exhibit a large amount of meteorological and oceanographic noise. EN occurs at intervals of 2-10 years (strong events every 13-70 years: e.g. 19251926, 1982-1983 and 1997-1998) with an average return period of 4 years. It may last between half a year and several years in duration (Fig. 3). Therewith ENSO constitutes the major intra-decadal variability in the Chilean-Peruvian coastal upwelling system. However, it should not be concealed that there may be a superposition by decadal climate oscillation, e.g. the Pacific Decadal Oscillation, and possibly also by global warming (Timmermann et al. 1999; Baumgartner and Ortlieb 2002) the effects of which may have begun to influence the development and intensity of EN and are yet far from being understood.

Some of the best data on climate impact available at this time refer to $\mathrm{EN}$ as a consequence of the fact that the two strong EN events 1982-1983 and 1997-1998 were exceptionally well documented (e.g. Barber and Chávez 1983; Chávez et al. 1999; Tarazona et al. 2001). Both events showed major differences concerning the signals of the marine biota. These different biological responses were apparently not due to different intensity of physical changes along the equator, but were rather related to the distinct seasonal onset of EN. The 1982-1983 EN event started in austral spring, just before the reproductive season and showed much stronger effects on marine communities of the Humboldt Current, than the EN 1997-1998 starting in austral autumn. For the northern hemisphere upwelling ecosystem of the California Current the impact has been reversely, according to the different reproductive periods by marine organisms (Arntz 2002).

Oceanographic changes associated with EN include Kelvin waves towards and along the coast and a rise of the near-shore sea level in the eastern Pacific connected with a deepening of the thermocline. Thus upwelling takes place only in the mixed layer without returning nutrients from the bottom water to the surface layer (Barber and Chávez 1983). Moreover, the trade wind stress driving the upwelling may be lowered. Further effects are an increment of the sea surface temperature (in extreme EN years up to $10^{\circ} \mathrm{C}$ ) during several weeks, alterations in water circulation and hence changes in advection, an increase of dissolved

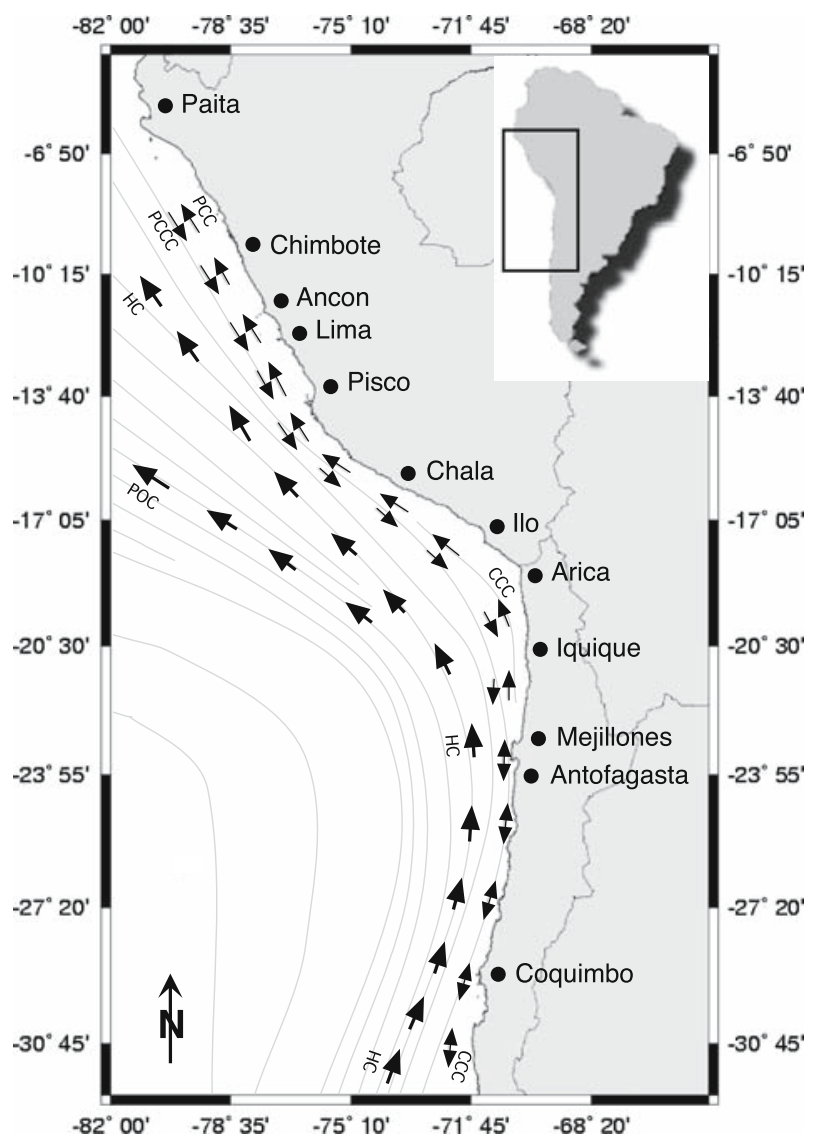

Fig. 1 Scheme of the surface currents off the studied South American Pacific coast, showing the main flow of the Humboldt Current (HC), the Chile Coastal Current (CCC), the Peru Coastal Current (PCC), the Peru-Chile Counter Current (PCCC) and the Peru Oceanic Current (POC)

oxygen concentration at the normally hypoxic soft bottoms of the Oxygen Minimum Zone (OMZ), agitated sea and changes in UV radiation (Arntz and Tarazona 1990; Tarazona and Arntz 2001).

Arid regions of Peru and Chile receive tremendously increased rainfall during strong ENs. Such heavy precipitation causes flash floods, river inundations, erosion, mudflows, and landslides. The flood-transported sediments spill dwellings, waterworks, roads, and cropland (Glantz 1984). The significant increase of fresh water input (which changes the surface salinity), the increased sediment load and associated nutrients to the coastal system is a major boundary condition for the near-shore marine ecosystem.

These oceanographic changes have drastic effects on the marine biota. However, the amount of changes to the ecosystem depends on the time of onset of the event, its duration and intensity, the distance from the main impact zone along the equator, and the water depth, among other factors (Arntz et al. 2006). Moderate, strong and very strong EN events are not only of meteorological, oceanographic and biological interest, but also have major economic, 
Fig. 2 Winter (March-November) sea surface temperature $\left({ }^{\circ} \mathrm{C}\right)$ anomaly showing (a) El Niño conditions (mean data from 1958, 1966, 1969, 1973, $1983,1987,1992,1999)$ and (b) La Niña conditions (mean data from 1955, 1956, 1965, 1971, 1974, 1976, 1989, 1999) (NOAA-CIRES Climate Diagnostics Centre, University of Colorado at Boulder, USA)
Fig. 3 Multivariate ENSO Index related to warm (positive) and cold (negative) conditions (NOAA-CIRES Climate Diagnostics Center, University of Colorado at Boulder)
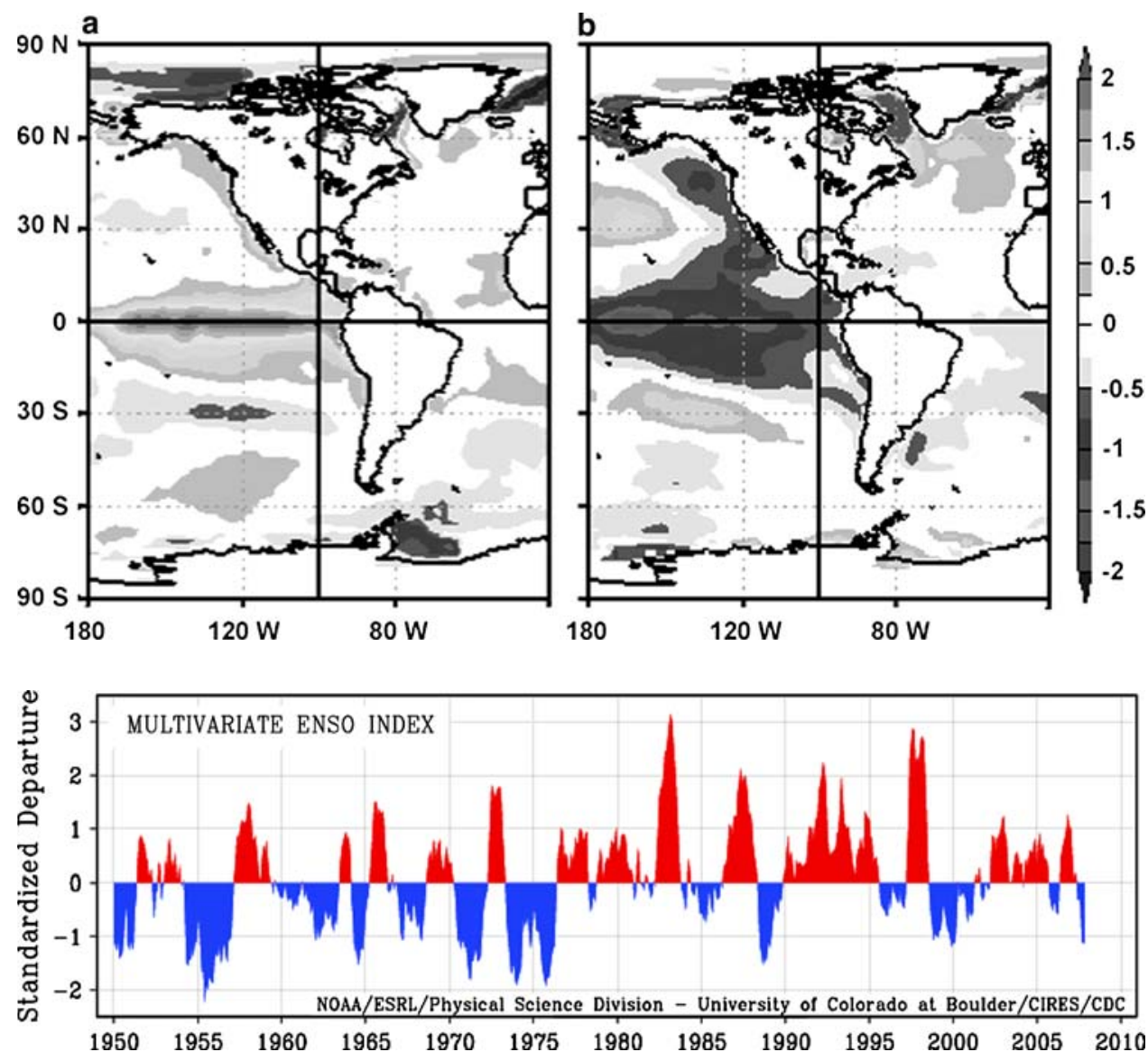

infrastructural and social consequences for the countries adjacent to the Pacific coast, which may amount to billions of USD (Arntz and Fahrbach 1991). Most of these impacts are direct and negative.

However, there are also positive effects provoked by EN. Under EN conditions soft-bottom hypoxia decreases in the OMZ (Kamykowski and Zentara 1990; Levin et al. 2002; Escribano et al. 2004) followed by an ecological succession to more mature stages and thus increasing diversity of benthic communities (Tarazona et al. 1988a, b, 1996; Gutiérrez et al. 2000; Peña et al. 2006). Additionally, mass development of certain species with commercial value for local artisanal and/or aquaculture industry such as the scallop Argopecten purpuratus, the gastropod Thais chocolata, and the octopus Octopus mimus are observed (Wolff 1987; Arntz et al. 1987, 1988). Exploitable species from tropical (warmer) waters or the open ocean immigrate in the normally cool coastal waters, including the staked barnacle Pollicipes elegans, various species of penaeid shrimps (Arntz et al. 1988) and many commercially exploited fish species of high value such as dolphinfish (Coryphaena hippurus) and scombrids (i.e. tuna) (Arntz and Fahrbach 1991; Lehodey 2001) (Table 1).

Each EN develops in a different way, and despite an enormous scientific effort including satellites, buoy arrays at the sea surface and to a lesser amount at depth, research vessels, merchant ships and coastal stations, its origins are still an unsolved problem. A timely prediction would be of high interest to the coastal human populations due to the socio-economic significance of this climate driven phenomenon. This is even more urgent since recent results indicate that in a realistic scenario of increasing greenhouse-gas concentrations more frequent EN-like conditions may have to be expected (e.g. Timmermann et al. 1999; IPCC 2007).

However, despite all modelling attempts (e.g. Harrison and Larkin 1998; Latif et al. 1998; McPhaden 1999) reliable prediction is not yet possible more than three months in advance. This also applies for biological prediction by means of indicator species. Spatial differences in EN effects are apparent (i.e. Laudien et al. 2007) and seemingly depend on the intensity of EN, but remain little considered in current management approaches.

\section{Reconciling multiple demands on coastal zones}

The CENSOR project aims to help reconciling the multiple demands on limited resources, in particular artisanal fishery resources, in the coastal zone of the Humboldt Current ecosystem. The most effective way to mitigate this situation is 
to improve the knowledge and predictive capabilities in order to allow a proper balance between the sustainable use of natural marine resources and the economic and socioeconomic requirements. Marine scientists are therefore increasingly trying to understand the environmental effects of specific climatic conditions (EN/LN) on marine ecosystems with the aim to advise decision makers on the rational use of natural resources. Single research disciplines cannot provide the necessary information for integrated ecosystem management, since they are unable to cover all relevant scientific aspects for sound ecosystem management.

The value of biological approaches to EN, besides the definite confirmation of an event (including predictions by utilizing, e.g. indicator species), nowadays refers rather to the accumulated long-term experience then to short-term negative or positive effects. Both the abiotic environmental changes and the biotic responses are largely recurrent, i.e. they usually occur at the same localities, and the organisms concerned always react in very similar ways. However, in most cases an early warning of EN a few months in advance would provide the opportunity of reacting to certain well-known changes or impacts.

This knowledge, and if applied in time, could prevent considerable damage and allow better use of alternatives. The indicators of EN events resulting from organismal and ecosystem studies could become substantial and sustainable tools to be used in early warning/prediction systems and thus relevant to managers of environmental quality control and sustainable development, not only along Pacific South America.

\section{The ecosystem (organismal) approach to coastal ENSO research}

The CENSOR consortium identified four complementary research areas that need particular addressing in order to enable the development of a comprehensive ecosystem management approach along the Pacific coast off South America, and which are summarized as follows:

\section{Coastal benthic communities}

The relative influence of nutrient availability ("bottom-up") versus predation ("top-down") as the main forces controlling community structures and dynamics has been debated for a variety of habitats and is particularly important in upwelling areas (Fig. 4). The different primary producers supporting coastal food webs may be benthic microalgae (Sullivan and Moncreif 1990), macroalgae or phytoplankton (Deegan and Garritt 1997), which can be fostered by nutrient input through watersheds (Valiela et al. 1997). Studies of coastal community responses to nutrient

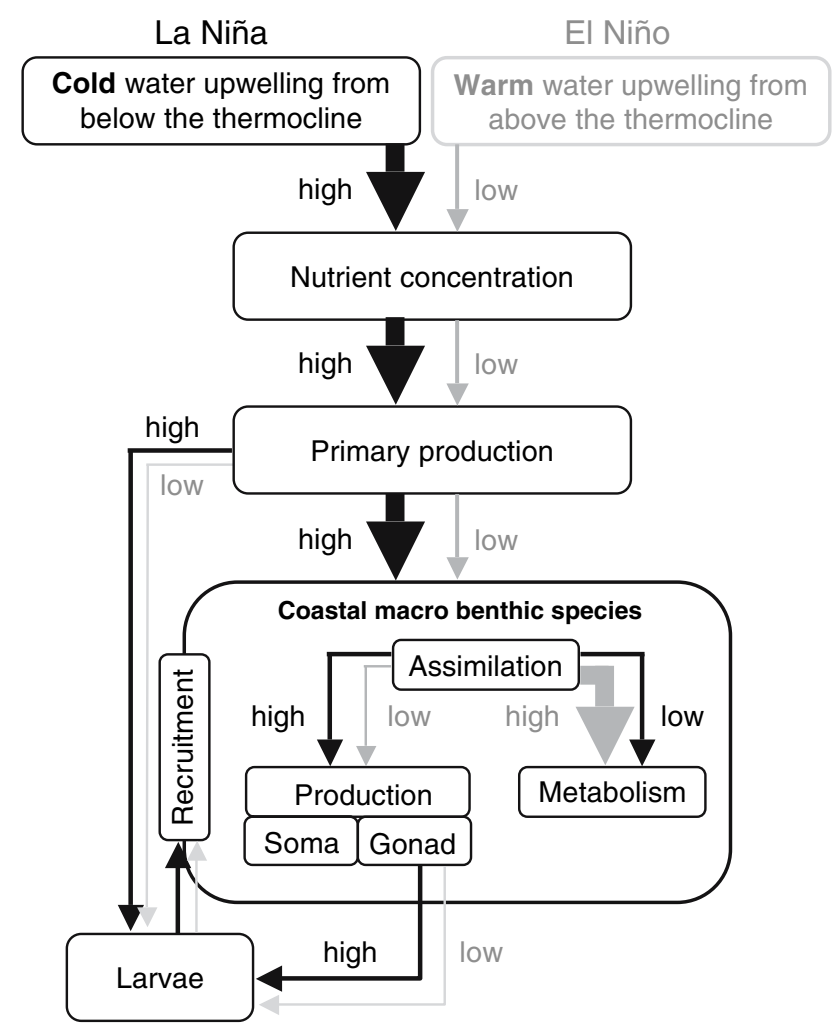

Fig. 4 Owing to the high concentration of nutrients, the Humboldt Current upwelling system is the most productive marine ecosystem of the world. Upwelling fuels high primary and secondary production by bringing nutrient-rich water to the surface layers. Under El Niño conditions water temperature increases and the thermocline drops, which limits upwelling to the nutrient-poor surface layer. This in turn reduces primary production. Thus, less energy can be assimilated by suspension feeding coastal marcobenthic species. Additionally, increased temperatures impact the organisms. Even when temperatures are not lethal, more energy is necessary for metabolism under stress. This means a greater amount of energy has to be allocated to metabolic energy and less "surplus" energy is available for reproduction and somatic growth. Temperature is often a trigger for the reproductive cycle, thus the temperature increase during EN may cause changes in an existing rhythm

enhancement showed inconsistent results, apparently because their trophic connections include a higher diversity of primary producers and consumers. Thus, coastal food webs may be more resilient to changes in sources of primary production or predation level (and hence harvesting). EN changes the availability of nutrients, and thus it is likely that community control (and production of commercial marine resources) switch from being bottom-up to be topdown controlled (Hidalgo et al. 2008). Information from recent moderate and strong EN events (e.g. 1982/1983, 1987/1988, 1991-1993, 1997/1998) as well as LN events (like the strong and longer than usual 1998-2001 event) demonstrated differences in the resilience potential of coastal communities (Laudien et al. 2007; Moreno et al. 2008). 
Larval supply to coastal communities is another major structuring force (Underwood 1997; Grosberg and Levitan 1992), which is highly affected by EN. Also, LN impacts recruitment rates by decreased water temperature and thus growth and reproductive output and/or changes in larval transport (Navarrete et al. 2002).

A third driving factor is ecosystem engineering (sensu Jones et al. 1994), which refers to the changing of habitats by organisms. Shells and structures of macroalgae are good examples, which modify the mortality rate of many species (Gutiérrez and Iribarne 2000; Gutiérrez et al. 2003) and provide a suitable habitat. Given that one characteristic manifestations of EN is the proliferation of local molluscs (A. purpuratus, T. chocolata; e.g. Arntz et al. 1987, 1988; Wolff 1987), ecosystem-engineering effects are potentially important in EN main impact areas.

\section{Pelagic-benthic processes and terrestrial impact}

EN causes changes in oceanographic conditions (i.e. nutrient poor upwelling) in both space and time. Pelagic populations have to cope with these altered conditions. Therefore, the understanding of physical-biological interactions in the water column of upwelling systems provides important insight into the key processes that control production and population dynamics of pelagic species (Escribano et al. 2002, 2004). For the Humboldt Current upwelling area, two key study areas for the understanding of pelagic-benthic processes are

(1) The mechanisms, through which the changes in the physico-chemical structure of the water column affect the coastal ecosystem (Fig. 4). The OMZ appears as prime candidate for a key mechanism, which transfers the climate signal to the ecosystem and affects the productivity and carbon flux in the near shore region; hence, the feeding conditions for shallow benthic organisms (Gutiérrez et al. 2000; Escribano et al. 2004). While a general concept of the role of the OMZ has been developed recently (Escribano et al. 2004) dedicated measurements are still lacking for a more detailed understanding of the mechanisms involved.

(2) The retention mechanisms that enable plankton, meroplankton, and fish larvae to successfully complete their life cycle in coastal waters. For some species regional studies have shown a complex interaction between the organisms and the hydrography (Arntz and Fahrbach 1991; Escribano et al. 2002). These studies need complementation by studying key fish larvae and meroplankton species.

EN/LN are associated with a regime shift in the pelagic system, from the classic diatom-large copepods-fish food chain to a microbial dominated system of bacteria-flagellates-microzooplankton-small copepods, which directly affects the feeding conditions in the pelagic and indirectly in the benthos through changes in the settling particle fluxes (Escribano et al. 2004; Noethig and Gowing 1991; Thiel et al. 2007). Nevertheless, phytoplankton biomass and production apparently do not change significantly during the ENSO cycle (Escribano et al. 2004). Studies of trophic interactions in the pelagic and the effect on the particle flux to the benthos are still lacking and are necessary for the understanding of energy flux shifts during ENSO.

It is well known, that vertical biogenic-particle fluxes (e.g. C, N) may be greatly influenced by changes in the community structure of the pelagic realm (González et al. 2000). Such changes might result from population responses (e.g. plankton distribution) to varying oceanographic conditions driven by climate variations (e.g. ENSO). However, in the coastal zone of the Humboldt Current System the relationships among these processes are far from being understood, despite the fact that modern oceanography clearly accepts the idea that biogenic flux of and their underlying mechanisms are key issues relating climate change and associated ecosystem responses.

El Niño events heavily affect the continental areas in Peru and Chile, ranging from intense droughts particularly in the high Andes to tremendously increased rainfall in arid regions of these countries. Such heavy precipitation causes flash floods, river inundations, erosion and landslides. The transport of water and sediments to the coastal system is intensified, being a major boundary condition for the coastal marine environment. Quantification of the flux of freshwater to the coastal marine system and to estimate related sediment transports are absent or locally restricted and the obvious terrestrial-marine interactions in sediment flow remain obscure. It is necessary to characterize and model the hydrological behaviour for EN/LN. This is important to quantify the average mass transport to the coastal marine system, and for defining the initial conditions for extreme events of runoff generation, erosion or landslides.

Ecophysiological constraints and aquacultural demands

Studies of coastal ecosystems in the Humboldt Current system off South America traditionally have been rather descriptive. Data acquisition on macrobenthic communities and/or the pelagic regime over time revealed changes in, e.g. abundance, biomass and biotic composition related to ENSO. However, the pattern underlying ecophysiological processes, which allow for explaining diversity and biogeographic shifts (Pörtner 2001), changes in growth patterns and reproductive traits related to ENSO, remain principally undefined. One of the parameters usually indicating 
changing climate is decreasing or increasing temperature (Schellenhuber and Sterr 1993). Temperature changes can affect, directly or indirectly, marine populations during all life stages (Urban 1994; Pörtner 2001; Heilmayer et al. 2004). Assessing the influence of changing temperature regimes as indicative of decadal-scale climate variation or change on the adult stages of key species, including invaders during EN (such as shrimp, Xiphopenaeus riveti) as well as such species, which suffer from mass mortality due to increased water temperatures associated to EN (e.g. Mesodesma donacium, Aulacomya atra, Cancer spp. Platycanthus orbignyi) is crucial to understand better how ENSO affects species biogeography and eventual mass mortalities of key species. Assessing physiological temperature limits in commercial or ecosystem key species is particularly important if we want to understand the vulnerability of these organisms in response of variable EN intensity. This could be key to short-term prediction of the availability of key organisms to fisheries during EN. Furthermore, it allows simple but necessary management advise as to the survival potential of natural and aquaculture stocks. Towards this goal, a profound synthesized knowledge of ecological and physiological processes is required which can only be gained by an interdisciplinary combination of ecological, physiological, genetic and modelling investigations.

From knowledge to resource management

Research to improve the understanding of coastal zones, to support the human communities living in and from this area, requires a shared interdisciplinary framework, in order to help reconciling the multiple demands on limited resources, mitigate degradation, and find equitable, innovative solutions appropriate to the social, economic, institutional and environmental contexts of developing countries (Nauen et al. 2006). This requires, in a first place, a detailed review, integration and dissemination of traditionally available datasets (published and unpublished resources, see Thatje et al. 2007) that serves the baseline to ecosystem studies and on top of which scientific gaps are identified. The traditionally descriptive data available from the coastal upwelling ecosystem off South America need augmentation by the results obtained from selected process studies, as outlined before, which aim to integrate and explain the universality of patterns for coastal upwelling systems elsewhere. Here, it is particularly important to distinguish between patterns related to climate dependent (EN) changes in coastal ecosystems and human impacts such as overexploiting economically important fishery targets. Additionally, terrestrial fluxes of water and sediment to the coastal zone, which tremendously differ between normal and EN-conditions have an impact on the coastal marine environment.
Multivariate models are one option to integrate data from various resources and to evaluate the overall effect of environmental (abiotic and biotic) conditions on community composition, species diversity and resource biomass (Taylor et al. 2008). Only the integrated analysis will allow for decisive understanding of coastal, ecosystem underlying processes in upwelling regions and will help to understand the response of communities to EN. This will enable direct advice to fisheries, politics, and ecosystem management/ restoration and aid to socio-economic stability in coastal upwelling zones.

\section{Coastal (artisanal) fisheries: lessons from Chile and Peru}

International trades have largely affected local fishing practice by setting the scene for economic demands, competition, and product value. The Chilean management approach of coastal natural marine resources is based on the "management area" (Spanish: area de manejo) approach, which gives local fishermen syndicate the right to manage an area assigned to them (Castilla 1996). The number of fishermen responsible for a management area strongly varies and can reach 150 individuals in larger syndicates; consequently does the size of the management area, which in a few cases may reach up to a 150 ha. Fishermen possess management rights for their management area but do not obtain any legislative or property rights from the government. The community has to pay monthly concession rights to the government; legal measures, however, such as control of illegal fisheries, is generally not enforced by the government. In consequence, syndicates are largely unable to protect their stocks from illegal fisheries, which is a major concern. Private company security controls are installed for some of the larger management areas, but cost implications involved prevent large-scale fisheries control along the coast and many smaller communities are thus unable to protect their stocks (Table 1).

The self-regulated management approach has given great independence to local fishermen in the exploitation of "their" resources and yielded some sustainability in income and over several years without EN (Castilla and Fernandez 1998). However, in Chile everyone who wants to work as a fisherman can subscribe to a register for free and without any necessary training/education background, which caused that within the last about 15 years the number of registered fishermen not part of a management area community has risen from about 1,500 to 15,000 individuals (Subsecretaría de Pesca, personal communication). Such a development causes to concern regarding the effectiveness of the management area approach, mainly because of the lack of governmental enforcement and effectively no 
Table 1 List of marine species of economic interest in commercial and artisanal coastal fisheries along Pacific South America

\begin{tabular}{|c|c|c|c|c|}
\hline Scientific name & Local (Spanish) name & $\begin{array}{l}\text { Landing in } \\
\text { northern Chile }{ }^{\mathrm{a}}(\mathrm{t})\end{array}$ & $\begin{array}{l}\text { Chile } \\
(\text { total, t) }\end{array}$ & $\begin{array}{l}\text { Peru }^{\mathrm{b}} \\
(\text { total, } \mathrm{t})\end{array}$ \\
\hline \multicolumn{5}{|l|}{ Algae } \\
\hline \multicolumn{5}{|l|}{ Rhodymenia sp. } \\
\hline Macrocystis pyrifera & Huiro/Sargazo & & & \\
\hline Lessonia nigrescens & Chascón/Aracanto & 9,672 & 16,500 & \\
\hline Lessonia trabeculata & Huiro palo/Palo blanco & 3,391 & 18,457 & \\
\hline \multicolumn{5}{|l|}{ Molluscs } \\
\hline Mesodesma donacium & Macha & & 1,396 & 1 \\
\hline \multicolumn{5}{|l|}{ Donax marincovichi, D. peruvianus } \\
\hline D. obesulus, and D. mancorensis & Machilla/Palabritas & & & \\
\hline Argopecten purpuratus & Ostión del norte/Concha de abanico & $458^{\mathrm{c}}$ & 18,806 & 20,063 \\
\hline Thais chocolata & Caracol/Locate & 824 & 825 & 2,815 \\
\hline Concholepas concholepas & Chanque/Loco/Tolina & $9^{d}$ & 828 & \\
\hline Aulacomya ater & Cholga & 471 & 8,390 & 3,893 \\
\hline Trachycardium procerum & Concha Corazon & & & \\
\hline Octopus mimus & Pulpo & 1,613 & 2,080 & \\
\hline Fissurella sp. & Lapa & $807^{\mathrm{e}}$ & 2,597 & \\
\hline \multicolumn{5}{|l|}{ Crustaceans } \\
\hline Emerita analoga & Pulguilla del mar/Muy Muy & & & \\
\hline Pollicipes elegans & Percebes & & & \\
\hline Cancer setosus/polyodon & Cangrejo peludo ${ }^{\mathrm{f}}$ & 62 & 387 & $5,069^{\mathrm{g}}$ \\
\hline Cancer porteri & Cangrejo/Jaiba & & & \\
\hline Xiphopenaeus riveti & Camarón tití/Langostino tití & & & \\
\hline Homalaspis plana & Cangrejo/Jaiba & & & \\
\hline Platyxanthus orbignyi & Cangrejo/Jaiba/cangrejo violádo & & & \\
\hline \multicolumn{5}{|l|}{ Echinoderms } \\
\hline Loxechinus albus & Erizo & 4,459 & 46,794 & 369 \\
\hline \multicolumn{5}{|l|}{ Fishes } \\
\hline Medialuna ancietae & Acha & & & \\
\hline Semicosyphus darwini & Pejeperro & 24 & 33 & \\
\hline Cynoscion analis & Ayanque/Cachema & & & 7,247 \\
\hline Cilus gilberti & Corvina & 16 & 1,033 & \\
\hline Paralabrax humeralis & Cabrilla & 83 & 101 & 4,672 \\
\hline
\end{tabular}

Approximate landings for Chile and Peru (data from Sernapesca 2001; IMARPE 2003); all values in tons (t), empty spaces denotes no quantitative data available

a Data from Antofagasta and Iquique for 2000 (SERNAPESCA 2001)

b Data for 2002 (IMARPE 2003)

${ }^{\mathrm{c}}$ Extraction prohibited. Landing correspond to farmed scallops

d Species with management measures based on quotes

e More than three species of Fissurella are landing under the common name of "Lapas" in northern Chile, but in southern Chile four species are recognized in landing records. Chilean landing includes the total for the four species

${ }^{\mathrm{f}}$ In the landing report only one "crab" is registered in northern Chile (Jaiba peluda = Cancer setosus) but at least other eight fished crabs species are reported for the total of the country

g Species or common name not indicated

control on fishing licenses. Due to this development, the situation outside management areas for many artisanal resources such as the gastropod Concholepas concholepas ("loco") has become critical (Castilla and Fernandez 1998; Fernandez 2005).
The lack or only sporadic control for illegal fisheries in the near-shore environment caused that many management area communities needed to increase inversions into security by means of credits, which are often encouraged by cash crop enterprises and cause financial dependencies. 
In theory, the "area de manejo" approach could develop a powerful tool against overexploitation of many coastal resources; however, local fishermen communities will require more socio-economic and political support in order to be enabled to cope with the challenges involved that derive from the ecological needs of sustainability and the economic demands on coastal marine resources and human populations.

Current management concepts have widely ignored the fact that the resilience potential and time of recovery of marine communities slows down with increasing latitude because of lower temperatures. Marine resources with a wide latitudinal distribution range such as many shellfish species off Pacific South America, are likely to mature later and at smaller size, and grow slower with increased latitude (Urban 1994). This does indeed complicate management of size at maturity, legal fishing size, and fishing quota, to mention just a few, and current fishing regulations tend to apply universal rules along the Pacific coast of Chile.

The situation of the Peruvian artisanal fisheries remains by far more obscure and largely depends on self-organisation of fishermen. Lack of enforcement in the control of fisheries is certainly a problem. The major difference with Chile, however, is the principal lack of management areas that help developing some degree of self-awareness and responsibility although there exist some local fishermen that demonstrate clear awareness of the problem, but with no legislative support. Furthermore, Peruvian artisanal fleets tend to move to where the targeted stocks are (Arntz and Fahrbach 1991), which causes migratory behaviour and aggregations of artisanal fishing boats in certain areas along the coast. Under these circumstances, and without assigned fishing rights and control, a sustainable management is rather difficult and puts the targeted stocks at risk.

\section{Conclusions}

The successful implementation of ecosystem management plans requires the perceptions and willingness by each participatory group to hear and integrate the messages brought forward by the different stakeholders involved in this process (Nauen et al. 2006). Mitigating the effects of climate oscillation events, such as EN, on coastal ecosystems, are especially challenging because of their unpredictability in strength and small-scale variability in impact. As outlined here, efforts in bringing together the traditionally controversial socio-economic approaches and natural scientific analyses is essential if we are to enhance the management impact of marine ecosystems in general; a concept, which does not only apply to the Humboldt Current system alone. Differences in traditional fisheries, as briefly outlined for
Chile and Peru, furthermore complicate the development and application of management tools.

Organism biology holds one key to small-scale management advice, as a stepping-stone to more flexile and useroriented, large-scale management approaches. This bottomup approach is certainly different from large-scale topdown management concepts currently in place for most of the ocean (i.e. ITQs). Small-scale management is also needed to protect traditionally more sustainable artisanal fisheries from industrial-scale operations, which are by far more destructive and part of globally driven economy. Strengthening artisanal fisheries will not only enable a more sustainable use of local natural resources, but also support the livelihood of coastal communities by fostering local economy, and social stability of the regions concerned.

Acknowledgments We would like to thank the European Commission for supporting the CENSOR (http://www.censor.name) project within the FP6-INCO-STREP programme (CENSOR-I-CT-2004511071). Financial support to the project through the Comisión Nacional de Investigación Científica y Tecnológica (CONICYT, Chile), and the Alfred Wegener Institute for Polar and Marine Research (Helmholtz Association, Germany) is greatly acknowledged. We are grateful to the entire CENSOR Consortium for the realisation of this project and for also making this international cooperation an enjoyable experience. Special thanks are due to Betina Lomovasky, Oscar Iribarne, Hans-Jürgen Hirche, Rubén Escribano, Luc Ortlieb, and Enrique Isla, who greatly contributed to the conceptual planning of this project at its initiation. This is CENSOR publication No 032.

\section{References}

Arntz WE (2002) The role of El Niño, La Niña and climate change in the Pacific Eastern Boundary Currents: an integrated introductory view. In: Salinas S, Urban H-J, Arntz WE (eds) Extended abstracts of the symposium "Impacts of El Niño and basin-scale climate change on ecosystems and living resources: a comparison between the California and the Humboldt current systems". Invest Mar 30:81-82

Arntz WE, Fahrbach E (1991) El Niño-climate experiment of nature. (In German, Spanish edn in 1996) Birkhäuser, Basel, 264 pp

Arntz WE, Tarazona J (1990) Effects of El Niño on benthos, fish and fisheries off the South American Pacific coast. In: Glynn PW (ed) Global ecological consequences of the 1982-83 El Niño-Southern Oscillation. Elsevier Oceanogr Ser 52:323-360

Arntz WE, Brey T, Tarazona J, Robles A (1987) Changes in the structure of a shallow sandy-beach community in Peru during an El Niño event. SA J Mar Sci 5:645-658

Arntz WE, Valdivia E, Zeballos J (1988) Impact of El Niño 1982-83 on the commercially exploited invertebrates (mariscos) of the Peruvian shore. Meeresforsch 32:3-22

Arntz WE, Gallardo VA, Gutiérrez D, Isla E, Levin LA, Mendo J, Neira C, Rowe GT, Tarazona J, Wolff M (2006) El Niño and similar perturbation effects on the benthos of the Humboldt, California, and Benguela Current upwelling ecosystems. Ad Geo 6:243-265

Barber RT, Chávez FP (1983) Biological consequences of El Niño. Science 222:1203-1210

Baumgartner T, Ortlieb L (2002) Interdecadal and centennial variability underlying the El Niño/La Niña System. Invest Mar 30:82-83 
Castilla JC (1996) La futura Red Chilena de Parques y Reservas Marinas y los conceptos de conservación, preservación y manejo en la legislación nacional. Rev Chil Hist Nat 69:252-270

Castilla JC, Fernández M (1998) Small-scale benthic fisheries in Chile: on co-management and sustainable use of benthic invertebrates. Ecol Appl 8:124-132

Chávez FP, Strutton PG, Friederich GE, Feely RA, Feldman GA, Foley D, McPhaden MJ (1999) Biological and chemical response of the equatorial Pacific Ocean to the 1997 and 1998 El Niño. Science 286:2126-2131

Deegan LA, Garrit RH (1997) Evidence for spatial variability in estuarine food webs. Mar Ecol Prog Ser 147:31-47

Escribano R, Marín V, Hidalgo P, Olivares G (2002) Physical-biological interactions in the pelagic ecosystem of the nearshore zone of the northern Humboldt Current System. In: Castilla JC, Largier J (eds) The oceanography and ecology of the Nearshore Bays in Chile. In: Proceedings of international symposium. Linkages and dynamics of coastal systems: open coast and embayments. Ediciones Universidad Católica de Chile. Santiago, pp 145-175

Escribano R, Daneri G, Farías L, Gallardo VA, González HE, Gutierrez D, Lange CB, Morales CE, Pizarro O, Ulloa O, Braun M (2004) Biological and chemical consequences of the 1997-1998 El Niño in the Chilean coastal upwelling system: a synthesis. Deep Sea Res II 51:2389-2411

Fernández M, Castilla JC (2005) Marine conservation in Chile: historical perspectives, lessons, and challenges. Conserv Biol 19:1752-1762

Glantz MH (1984) Floods, fires and famine: Is El Niño to blame? Oceanus 27:14-20

González HE, Sobarzo M, Figueroa D, Nöthig EM (2000) Composition, biomass, and potential grazing impact of the crustacean and pelagic tunicates in the northern Humboldt Current area off Chile: differences between El Niño and non-El Niño years. Mar Ecol Prog Ser 195:201-220

Grosberg R, Levitan DR (1992) For adults only? Supply-side ecology and the history of larval biology. Trends Ecol Evol 7:130-133

Gutiérrez J, Iribarne O (2000) Role of Holocene beds of stout razor clams in structuring present benthic communities. Mar Ecol Prog Ser 185:213-228

Gutiérrez D, Gallardo VA, Mayor S, Neira C, Vásquez C, Sellanes J, Rivas M, Soto A, Carrasco F, Baltazar M (2000) Effects of dissolved oxygen and fresh organic matter on the bioturbation potential of macrofauna in sublittoral sediments off Central Chile during the 1997/1998 El Niño. Mar Ecol Prog Ser 202:81-99

Gutiérrez JL, Jones CG, Strayer DL, Iribarne O (2003) Mollusks as ecosystem engineers: the role of shell production in aquatic habitats. Oikos 101:79-90

Harrison DE, Larkin NK (1998) El Niño/Southern Oscillation sea surface temperature and wind anomalies. Rev Geophys 36:353-399

Heilmayer O, Brey T, Pörtner HO (2004) Growth efficiency and temperature in scallops: a comparative analysis of species adapted to different temperatures. Funct Ecol 18:641-647

Hidalgo FJ, Firstater FN, Fanjul E, Cielo Bazterrica M, Lomovasky BJ, Tarazona J, Iribarne OO (2008) Grazing effects of the periwinkle Echinolittorina peruviana at a central Peruvian high rocky intertidal. Helgol Mar Res 62 (suppl 1). doi:10.1007/s10152-0070086-3

IPPC (2007) Intergovernmental panel on climate change fourth assessment report climate change 2007: synthesis report. http:// www.ipcc.ch/ipccreports/ar4-syr.htm

Jones CG, Lawton JH, Shachak M (1994) Organisms as ecosystem engineers. Oikos 69:373-386

Kamykowsi D, Zentara SJ (1990) Hypoxia in the world ocean as recorded on the historical data set. Deep Sea Res I 37:1861-1874

Latif M, Anderson D, Barnett T, Cane M, Kleeman R, Leetma A, O'Brien J, Rosati A, Schneider E (1998) A review of predictability and prediction of ENSO. J Geophys Res 103:375-394
Laudien J, Rojo M, Oliva M, Arntz WE, Thatje S (2007) Sublittoral macrozoobenthic communities and diversity of Mejillones Bay in northern Chile (Humboldt Current upwelling system). Helgoland Mar Res 61:103-116

Lehodey P (2001) The pelagic ecosystem of the tropical Pacific Ocean: dynamic spatial modelling and biological consequences of ENSO. Prog Oceanogr 49:439-468

Levin L, Gutierrez D, Rathburn A, Neira C, Sellanes J, Munoz P, Gallardo V, Salamanca M (2002) Benthic processes on the Peru margin: a transect across the oxygen minimum zone during the 199798 El Niño. Prog Oceanogr 53:1-27

McPhaden MJ (1999) Genesis and evolution of the 1997-98 El Niño. Science 283:950-954

Moreno RA, Badano EI, Sepulveda RD, Thatje S, Rozbaczylo N, Carrasco FD (2008) Subtidal macrozoobenthos communities from northern Chile during and post El Niño 1997-98. Helgol Mar Res 62 (suppl 1). doi:10.1007/s10152-007-0095-2

Nauen CE, Christensen V, Failler P, Opitz S, Thatje S (2006) Recovering fisheries from crisis or collapse: how to shorten impact time of international research cooperation. 13 pages. In: Shriver LA (ed) Proceedings of the thirteenth biennial conference of the international institute of fisheries economics and trade, 11-14 July 2006, Portsmouth, UK. Rebuilding Fisheries in an Uncertain Environment. International Institute of Fisheries Economics \& Trade, Corvallis, Oregon, USA, 2006. CD ROM. ISBN 0-9763432-3-1

Navarrete SA, Broitman B, Wieters EA, Finke GR, Venegas RM, Sotomayor A (2002) Recruitment of intertidal invertebrats in the southeast Pacific: interannual variability and the 1997-1998 El Niño. Limnol Oceanogr 47:791-802

Noethig E-M, Gowing MM (1991) Late winter abundance and distribution of phaeodarian radiolarians, other large protozooplankton and copepod nauplii in the Weddell Sea, Antarctica. Mar Biol 111:473-484

Peña TS, Johst K, Grimm V, Arntz W, Tarazona J (2006) Disentangling the effects of El Niño on a population of the polychaete Sigambra bassi in the Bay of Ancón, Peru. Ad Geo 6: 161-166

Pörtner HO (2001) Climate change and temperature dependent biogeography: oxygen limitation of thermal tolerance in animals. Naturwissensch 88:137-146

Schellenhuber HJ, Sterr H (1993) Klimaänderung und Küste. Springer, Berlin, pp 400

Sernapesca (2001) Anuario Estadístico de Pesca. Servício Nacional de Pesca. Ministerio de Economía, Fomento y Reconstrucción de Chile, Valparaíso

Sullivan MJ, Moncreif CA (1990) Edaphic algae are important component of salt marsh food webs: evidence from multi stable isotope analysis. Mar Ecol Prog Ser 121:99-116

Tarazona J, Salzwedel H, Arntz W (1988a) Oscillations of macrobenthos in shallow waters of the Peruvian central coast induced by El Niño 1982-83. J Mar Res 46:593-611

Tarazona J, Salzwedel H, Arntz W (1988b) Positive effects of "El Niño" on macrozoobenthos inhabiting hypoxic areas of the Peruvian upwelling system. Oecologia 76:184-190

Tarazona J, Arntz WE (2001) The Peruvian coastal upwelling system. Ecol Stud 144:229-244

Tarazona J, Arntz WE, Canahuire E (1996) Impact of two "El Niño" events of different intensity on the hypoxic soft bottom macrobenthos off the central Peruvian coast. Mar Ecol 17:425-446

Tarazona J, Arntz W, Valle S, Peña T (2001) Los índices de El Niño y del impacto sobre las comunidades bentónicas. In: Tarazona J, Arntz W, Castillo E (eds) El Niño en América Latina: impactos biológicos y sociales. CONCYTEC. Lima pp 113-125

Taylor M, Wolff M, Vadas F, Yamashiro C (2008) Trophic and environmental drivers of the Sechura Bay Ecosystem (Peru) over an ENSO cycle. Helgol Mar Res 62 (suppl 1). doi:10.1007/s10152007-0093-4 
Thatje S, Laudien J, Heilmayer O, Nauen CE (2007) Understanding El Niño-the importance of Grey Literature in coastal ecosystem research and management. Mar Policy 31:85-93

Thiel M, Macaya EC, Arntz WE, Bastias H, Brokordt K, Camus PA, Castilla JC, Castro LR, Cortes M, Dumont CP, Escribano R, Fernandez M, Gajardo JA, Gaymer CF, Gomez I, Gonzalez AE, Gonzalez HE, Haye PA, Illanes JE, Iriarte JL, Lancellotti DA, Luna-Jorquera G, Luxordo C, Manriquez PH, Marin V, Muños P, Navarrete SA, Perez E, Poulin E, Sellanes J, Sepulveda HH, Stotz W, Tala F, Thomas A, Vargas CA, Vasquez JA, Vega JMA (2007) The Humboldt Current System of northern and central Chile. Oceanogr Mar Biol Ann Rev 45:195-345

Timmermann A, Oberhuber J, Bacher A, Esch M, Latif M, Roeckner E (1999) Increased El Niño frequency in a climate model forced by future greenhouse warning. Nature 398:694-697
Underwood A (1997) Experiments in ecology. Their logical design and interpretation using analysis of variance. Cambridge University Press. Cambridge pp 504

Urban H-J (1994) Upper temperature tolerance of ten bivalve species off Peru and Chile related to El Niño. Mar Ecol Prog Ser 107:139-145

Valiela I, McClelland J, Hauxwell J, Behr PJ, Hersh D, Foreman K (1997) Macroalgal blooms in shallow estuaries: control and ecophysiological and ecosystem consequences. Limnol Oceanogr 42:1105-1118

Wolff M (1987) Population dynamics of the Peruvian scallop Argopecten purpuratus during El Niño phenomenon of 1983. Can J Fish Aquat Sci 44:1684-1691 